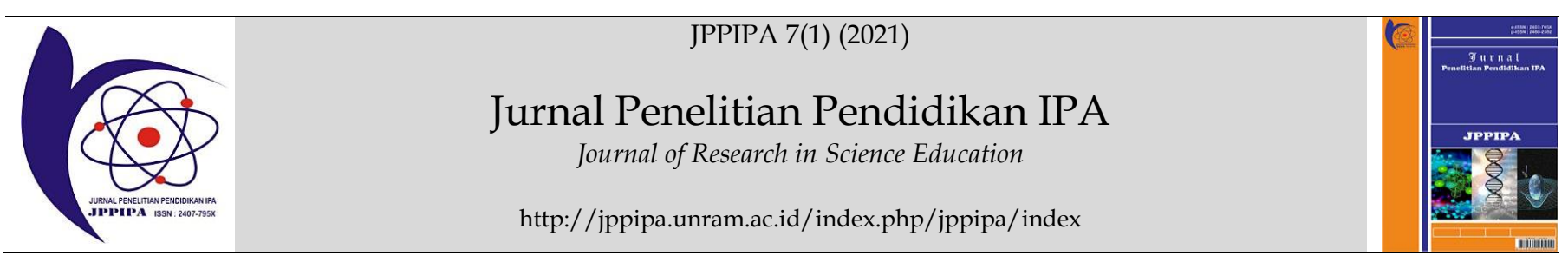

\title{
The Effect of Interactive Multimedia and Learning Styles on Students' Physics Creative Thinking Skills
}

\author{
Syahriani Yulianci ${ }^{1}$, Nurjumiati $^{*}$, Asriyadin², Adi Apriadi Adiansha1 \\ ${ }^{1}$ Elementary School Teacher, STKIP Taman Siswa Bima, NTB, Indonesia \\ 2Department of Physics Education, STKIP Taman Siswa Bima, NTB, Indonesia
}

\section{DOI: $10.29303 /$ ippipa.v7i1.529}

\section{Article Info}

Received: November $15^{\text {th }}, 2020$

Revised: January $7^{\text {th }}, 2021$

Accepted: January 18 th 2021

\begin{abstract}
One of the innovations in physics learning needs to be done by using creative learning media, namely interactive multimedia. This is done so that physics learning becomes more effective and not monotonous towards the delivery of material by the teacher. In addition to media factors, factors from within students need to be studied to improve the quality of learning physics. This study aims to test the effectiveness of interactive multimedia on students' creative thinking skills in physics. In addition, this study aims to influence learning styles on creative thinking skills and to see the interaction between interactive multimedia and learning styles in influencing creative thinking skills. This research is included in the quasi-experimental research. The total sample consisted of 74 tenth grade students, who were divided into two groups, namely the experimental class and the control class. The sample was determined by purposive sampling. Data on creative thinking skills were tested using N-Gain, and learning styles were analyzed quantitatively. To see the effectiveness of the research variables, an Anava test was performed. The results showed that interactive multimedia had an effect on students 'creative thinking skills, while the learning styles and interactions of the two independent variables did not affect students' creative thinking skills.
\end{abstract}

Keywords: Interactive multimedia; learning style; creative thinking skills; physics education.

Citation: Yulianci, S., Nurjumiati, N., asriyadin, A., \& Adiansha, A. (2021). The Effect of Interactive Multimedia and Learning Styles on Students' Physics Creative Thinking Skills. Jurnal Penelitian Pendidikan IPA, 7(1), 87-91. doi:https://doi.org/10.29303/jppipa.v7i1.529

\section{Introduction}

The use of learning media is an important factor that affects the achievement of learning objectives. So that the learning media used should be adjusted to the characteristics of the material being taught, or the learning model used. The development of science and technology in the field of education makes educators able to always be creative, including in the use of media (Henriksen et al., 2016). One of the media that is growing rapidly in line with the development of science and technology is an interactive multimedia (Dalle et al., 2017). Interactive multimedia is a learning medium that uses computers in the application process.
Interactive multimedia can be accessed easily on the internet and can be used offline or online. In physics learning, there are many interactive multimedia that have been developed, ranging from material that is abstract or concrete as well as from material that is macro to micro. The use of interactive multimedia can provide a new atmosphere in learning physics (Wiana, 2018). Students are able to understand abstract things that can be visualized into interactive multimedia. Including momentum and impulse material is material that is interesting to be visualized in interactive multimedia.

In recent years, a lot of research has focused on developing computer-based media, including Simulasi Physics Education Technology (PhET) (Khairunnisak, 
2017), interactive multimedia and virtual laboratory (Hermansyah et al., 2019); (Sanggara et al., 2018); (Masril, 2018) and e-book interactive (Adawiyah et al., 2019). Learning outcomes are important things that always want to be improved in the learning process. One of them is by using interactive multimedia. Some research on interactive multimedia is able to hone skills in students among them Husein et al., (2019) and Jamuri et al., (2015) able to increase mastery of concepts, Gunawan et al., (2019) able to improve the disposition of thinking and (Yulianci et al., 2018) able to improve student's generic science skill.

In the learning process, students are the most important subjects in using interactive multimedia. So that the factors that exist in students are very closely related to the learning process. The learning style of students is one of these important factors. In general, learning styles are divided into three, namely Visual, Auditory, and Kinesthetic (VAK). Every student has a different learning style tendency, although there is a possibility that he has all three (Balta, 2018). This learning style has different characteristics. Leasa et al., (2017) Visual students are able to receive information through the sense of sight, while auditory learning styles through hearing, and kinesthetic learning styles through touch.

This article will discuss three main objectives in this study, namely to test: (1) the effect of using interactive multimedia on creative thinking skills, (2) the influence of learning styles on creative thinking skills, and (3) interactive multimedia interactions and learning styles in influencing creative thinking skills of students.

\section{Method}

This research is quasi-experimental. The aim is to test certain treatments on the variables under study. The independent variables in this study are interactive multimedia and learning styles. Meanwhile, the dependent variable is the creative thinking skills of physics students. The research was conducted in class $X$ at one of the Senior High Schools in the Bima district. The sampling technique was purposive sampling. The sample consisted of 74 students who were divided into two classes, namely 38 students in the experimental class and 36 students in the control class.

This study used a pretest-posttest control group design. The stages of the research carried out were divided into three stages consisting of the initial stage, the implementation stage, and the final stage. Based on the method of implementation, the early stages of students were given a preliminary test of creative thinking skills and learning style instruments. At the stage of implementing the experimental class, the learning process uses a guided inquiry model with the help of interactive multimedia. Meanwhile, the control class learning only uses the inquiry model. The interactive multimedia used contains Momentum and Impulse material. In the final stage, the creative thinking skills test was conducted again. Data resulting from creative thinking skills and learning styles will be processed quantitatively. Also, to test the improvement of creative thinking skills using the N-Gain test, while to test the effectiveness of the media using Anava.

\section{Result and Discussion}

This study uses interactive multimedia on momentum and impulse materials that have previously been developed by researchers. In interactive multimedia, momentum and impulse materials are presented in the form of text, images, audio, and video. The matter is divided into three parts, namely momentum, impulse, and collision. Each part of the material has a different example of the problem.

Learning on this material is carried out in four meetings. At each meeting always use interactive multimedia combined with the guided inquiry model for the experimental class, while the control class only uses the guided inquiry model without interactive multimedia. The guided inquiry model is often used by teachers in the school environment, it's just that the media used is not like interactive multimedia. So this research is a new thing at the school.

Interactive multimedia used, at the development stage, has elements of learning styles, namely visual, auditory and kinesthetic learning styles. So that in the learning process it is not only one learning style that benefits. In other words, all students who have a tendency to different learning styles can use interactive multimedia to develop their creative thinking skills.

The use of interactive multimedia in the learning process is expected to improve students' creative thinking skills on momentum and impulse material. Data on students' creative thinking skills can be seen in Table 1.

Tabel 1. The Trend of Learners' Learning Styles

\begin{tabular}{llll}
\hline Class & Learning Style & Responden & Average (\%) \\
\hline Control & V & 5 & 14 \\
& $\mathrm{~A}$ & 17 & 47 \\
& $\mathrm{~K}$ & 7 & 20 \\
& VA & 3 & 8 \\
\multirow{5}{*}{ Experiment } & $\mathrm{AK}$ & 4 & 11 \\
& $\mathrm{~V}$ & 5 & 13 \\
& $\mathrm{~A}$ & 21 & 55 \\
& $\mathrm{~K}$ & 4 & 11 \\
& VA & 3 & 8 \\
& $\mathrm{AK}$ & 5 & 13 \\
\hline
\end{tabular}


The results of the identification of learning styles, there are five learning style tendencies including visual, audio, kinesthetic, a combination of visual and auditory, and a combination of auditory and kinesthetic. The two classes are dominated by auditory learning styles, namely 17 students in the control class and 21 students in the experimental class respectively. This dominating learning style can be caused by the habits of students and educators in carrying out the learning process. This has been said by Permatasary et al., (2018) that habit, environment, science and technology can influence the emergence of different learning styles for each individual.

In addition, the learning styles in the control class, respectively, from the lowest to the most are VA (3), AK (5), V (5), K (7), A (17). Whereas in the experimental class, successively from the lowest to the most were VA (3), K (4), AK (5), V (5), A (21). In the experimental class, visual learning styles and a combination of auditory and kinesthetic have the same number. The overall average number of learning styles in each class has an average that is not much different.

The unique thing that happened in these two classes was that there was no visible tendency for a combined visual and kinesthetic (VK) learning style. This shows that the learning process is rarely done visually or practically.

The next step is to test the effect of the independent variables on the dependent variable through the Anava test. Table 2 will present the results of the Anava test.

Table 2. Anava Test Results

\begin{tabular}{lllll}
\hline Source & df & F & Sig & The Result \\
\hline IM & 1 & 9.277 & 0.003 & $\mathrm{H}_{\mathrm{a}}$ Be accepted \\
LS & 4 & 1.203 & 0.319 & $\mathrm{H}_{\mathrm{a}}$ Rejected \\
IM ${ }^{\star}$ LS & 4 & 1.394 & 0.246 & $\mathrm{H}_{\mathrm{a}}$ Rejected \\
\hline
\end{tabular}

Interactive multimedia affects students' creative thinking skills, this is evidenced by the Anava test results shown in Table 2. This shows that there is a significant difference between the creative thinking skills of the control class and the experimental class when taught with interactive multimedia. The results of this study are from previous studies which prove that interactive multimedia can make learning more effective than those that do not use multimedia(Iskandar et al., 2018);(Nusir et al., 2013);(Yulianci et al., 2017).

During the learning process in the experimental class, the interactive multimedia used did not have problems at each stage. The interactive multimedia used is sufficient to make students understand impulse and momentum material. In addition to the material, in interactive multimedia, there are also examples of questions and practice questions that are open-ended, so that they can make students more creative in thinking about finding solutions. Also, the display of the media used is quite attractive to students with various colors, and there are supporting videos on each part of the material on momentum and impulse.

The second result of this study is the absence of the influence of students' learning styles on creative thinking skills. This is in contrast to several previous studies Zulfiani et al., (2020) that state that learning styles can affect learning outcomes. Based on research by Yulianci et al., (2019) there are several possibilities among which, the learning style instrument provided is unable to provide accurate information. The number of trends in learning styles varies considerably in each class. For example, audio learning styles dominate several times more than other learning styles.

The third result of this study is that there is no interaction between interactive multimedia and learning styles in influencing creative thinking skills. This means that interactive multimedia used does not depend on learning styles in influencing students' creative thinking skills.

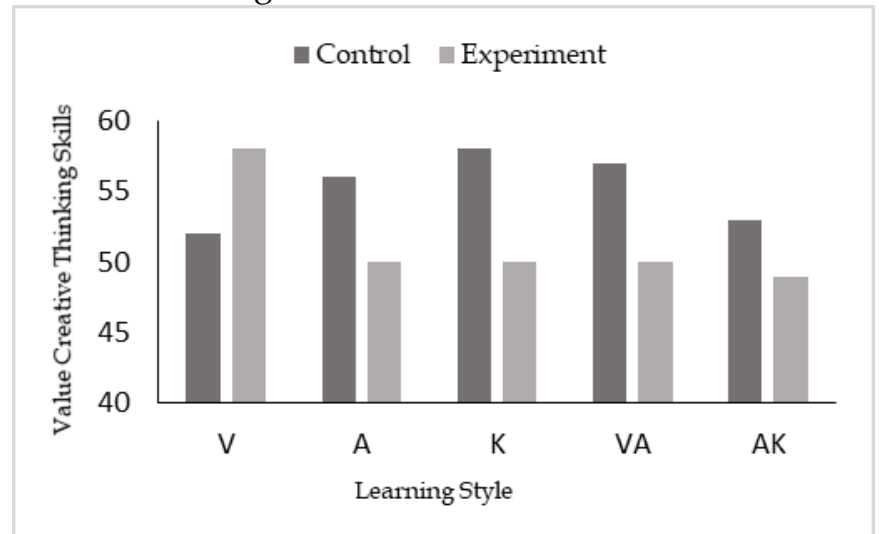

Figure 1. N-Gain Value of Creative Thinking Skills Based on Learning Styles

The unique thing found in this study is that students with visual learning styles have a higher value of improvement when compared to other learning styles as seen in Figure 1. This shows that interactive multimedia used in the experimental class provides its own benefits to those who have a visual learning style. It is different in the control class, which is only taught with a guided inquiry model without using interactive multimedia. students with kinesthetic learning styles are superior to other learning styles. This proves that the inquiry model is suitable for students who have kinesthetic learning style characteristics.

\section{Conclusion}

Based on the research objectives, the main conclusions include there is an effect of interactive multimedia on students' creative thinking skills in 
physics, there is no influence of learning styles on creative thinking skills, and there is no interaction between interactive multimedia and learning styles in influencing creative thinking skills of students.

In this study, it was also found that students with visual learning styles were shown to be able to have a higher increase in creative thinking skills when compared to other students with different learning styles through interactive multimedia learning. For future researchers in the same field, researchers suggest that the multimedia used is designed in such a way that students with learning styles other than visual can adapt to the learning process with the media used.

\section{Acknowledgements}

Researchers would like to give special thanks to the Directorate of Research and Community Service (DRPM) Kemenristekdikti for funding this research in 2020. Thank you also to the researchers at STKIP Taman Siswa Bima for their contributions and suggestions.

\section{References}

Adawiyah, R., Harjono, A., Gunawan, G., \& Hermansyah, H. (2019). Interactive e-book of physics to increase students' creative thinking skills on rotational dynamics concept. Journal of Physics: Conference Series, 1153(1). https://doi.org/10.1088/17426596/1153/1/012117

Balta, E. E. (2018). Reflective thinking tendencies and epistemological beliefs in terms of learning styles. International Journal of Higher Education, 7(6), 106117. https://doi.org/10.5430/ijhe.v7n6p106

Dalle, J., Hadi, S., Baharuddin, \& Hayati, N. (2017). The development of interactive multimedia learning pyramid and prism for junior high school using macromedia authorware. Turkish Online Journal of Educational Technology, 2017(Special Issue 2017), 714-721.

Gunawan, G., Harjono, A., Herayanti, L., \& Husein, S. (2019). Problem-based learning approach with supported interactive multimedia in physics course: Its effects on critical thinking disposition. Journal for the Education of Gifted Young Scientists, $7(4)$, 1075-1089. https:// doi.org/10.17478/jegys.627162

Henriksen, D., Mishra, P., \& Fisser, P. (2016). International Forum of Educational Technology \& Society Infusing Creativity and Technology in 21st Century Education: A Systemic View for Change Published by : International Forum of Educational Technology \& Society Infusing Creativity and
Technology in. Journal of Educational Technology $\mathcal{E}$ Society, 19(3), 27-37.

Hermansyah, H., Gunawan, G., Harjono, A., \& Adawiyah, R. (2019). Guided inquiry model with virtual labs to improve students' understanding on heat concept. Journal of Physics: Conference Series, 1153(1). https://doi.org/10.1088/17426596/1153/1/012116

Husein, S., Gunawan, Harjono, A., \& Wahyuni, S. (2019). Problem-Based Learning with Interactive Multimedia to Improve Students' Understanding of Thermodynamic Concepts. Journal of Physics: Conference Series, 1233(1). https://doi.org/10.1088/17426596/1233/1/012028

Iskandar, A., Rizal, M., Kurniasih, N., Sutiksno, D. U., \& Purnomo, A. (2018). The Effects of Multimedia Learning on Students Achievement in Terms of Cognitive Test Results. Journal of Physics: Conference Series, 1114(1). https://doi.org/10.1088/17426596/1114/1/012019

Jamuri, Kosim, Doyan, A. (2015). Pengaruh Model Pembelajaran Kooperatif Stad Berbasis Multi Media Interaktif Terhadap Penguasaan Konsep Siswa Pada Materi Termodinamika. Jurnal Penelitian Pendidikan IPA, 1(1), 123-134. https://doi.org/10.29303/jppipa.v1i1.11

Khairunnisak. (2017). Peningkatan Pemahaman Konsep dan Motivasi Belajar Siswa Melalui Simulasi Physics Education Technology (PhET). Jurnal Penelitian Pendidikan IPA (JPPIPA), 03(02), 0-12.

Leasa, M., Corebima, A. D., Ibrohim, \& Suwono, H. (2017). Emotional intelligence among auditory, reading, and kinesthetic learning styles of elementary school students in Ambon-Indonesia. International Electronic Journal of Elementary Education, 10(1), 83-91. https://doi.org/10.26822/iejee.2017131889

Masril, M. (2018). Penerapan Discovery Learning Berbantuan Virtual Laboratory Untuk Meningkatkan Kompetensi Fisika Siswa Sma. Jurnal Penelitian Pendidikan IPA, 5(1). https://doi.org/10.29303/jppipa.v5i1.160

Nusir, S., Alsmadi, I., Al-Kabi, M., \& Sharadgah, F. (2013). Studying the impact of using multimedia interactive programs on children's ability to learn basic math skills. E-Learning and Digital Media, 10(3), 305-319. https://doi.org/10.2304/elea.2013.10.3.305

Permatasary, Y., Purwoko, A. A., \& Muntari, M. (2018). Pengaruh Model Pembelajaran Problem Based Instruction Terhadap Hasil Belajar Ditinjau Dari Gaya Belajar Siswa. Jurnal Penelitian Pendidikan IPA, 4(1). 
https://doi.org/10.29303/jppipa.v4i1.104

Sanggara, P. W., Doyan, A., \& Verawati, N. N. S. P. (2018). The Effect of Process Oriented Guided Inquiry Learning Model Based on Virtual Laboraory Toward Problem Solving Abilities of Physics Student. Jurnal Penelitian Pendidikan IPA, 5(1), $1-5$. https://doi.org/10.29303/jppipa.v5i1.154

Wiana, W. (2018). Interactive Multimedia-Based Animation: A Study of Effectiveness on Fashion Design Technology Learning. Journal of Physics: Conference Series, 953(1). https:/ / doi.org/10.1088/17426596/953/1/012024

Yulianci S, Gunawan G, Aris Doyan, F. F. (2019). Pengaruh Penguasaan Pengukuran Terhadap Hasil Belajar Fisika Siswa Pada Materi Besaran Dan Satuan. Jurnal Pendidikan MIPA, 9(2), 123.

Yulianci, S., Gunawan, G., \& Doyan, A. (2017). Model Inkuiri Terbimbing Berbantuan Multimedia Interaktif Untuk Meningkatkan Penguasaan Konsep Fisika Peserta Didik. Jurnal Pendidikan Fisika Dan Teknologi, 3(2), 146. https://doi.org/10.29303/jpft.v3i2.365

Yulianci, S., Gunawan, G., \& Doyan, A. (2018). The Effect of Guided Inquiry Model with Interactive Multimedia Towards Student's Generic Science Skill Based on Learning Styles. Aes, 193-198. https://doi.org/10.5220/0007301001930198

Zulfiani, Suwarna, I. P., \& Sumantri, M. F. (2020). Science adaptive assessment tool: Kolb's learning style profile and student's higher order thinking skill level. Jurnal Pendidikan IPA Indonesia, 9(2), 194-207. https://doi.org/10.15294/jpii.v9i2.23840 